\title{
保育中の活動場面による身体活動水準の違い 一活発な子どもと不活発な子どもの比較一
}

石沢 順子 ${ }^{1}$ 佐々木玲子 ${ }^{2}$ 松訔 洋子 $^{3}$ 吉武 裕 ${ }^{4}$

\section{Differences in preschoolers' physical activity levels across conditions involving different levels of activity in nursery school : a comparison between children subjectively assessed as active or inactive}

\author{
Junko Ishizawa ${ }^{1}$, Reiko Sasaki ${ }^{2}$, Yoko Matsuzaki ${ }^{3}$ and Yutaka Yoshitake
}

\begin{abstract}
Many studies have examined preschoolers' physical activity (PA) in nursery school settings. They suggest that PA in this age group is influenced by factors such as age, gender, and size of playground. The present study compares the PA level of "active" or "inactive" children, as subjectively assessed by nursery school teachers, and uses accelerometry to examine how their PA levels differ across several conditions, involving different levels of activity, in nursery schools. PA was assessed using a triaxial accelerometer (Active Style Pro, Omron) for 5 weekdays in nursery school. We examined the time children spent in moderate-tovigorous activity (MVPA) during free play and structured physical activity periods (in the playroom, playground, and nearby parks). MVPA was higher in the "active" children than in the "inactive" ones, throughout the time spent in nursery school and free play. However, during structured physical activities, both groups had similar MVPA levels. In particular, during outdoor structured activities in the playground and parks, both group had high PA levels. Locomotor activities accounted for most of the children's MVPA during outdoor activities, while non-locomotor activities were predominant in indoor play as compared to outdoor play. These results suggest that structured physical activities are effective in increasing the MVPA levels of particularly "inactive" children. Further, outdoor plays are especially important to increase the PA levels of all kinds of children.
\end{abstract}

Key words : preschool children, accelerometer, physical activity, step count 幼児，加速度計，身体活動，歩数

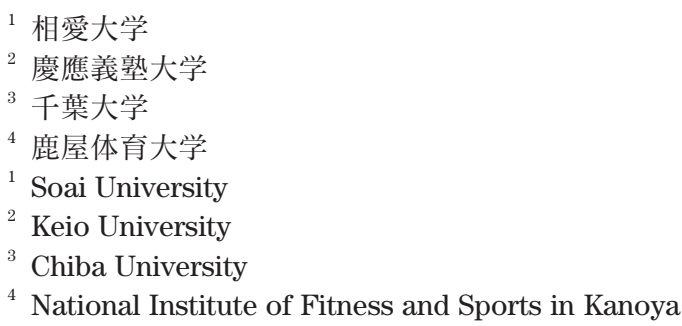




\section{I はじめに}

近年, 幼児期・学童期の子どもたちの体力・運 動能力の低下や肥満の増加が問題になっており, この原因のひとつとして日常生活での身体活動機 会の減少が挙げられている. 先行研究では子ども の時期に脂肪細胞数が増加することや運動不足が 慢性疾患のリスクを高めることなどが報告されて おり (Andersen et al., 2006 ; Spalding et al., 2008), 子どもの身体活動は将来の健康に大きな影響を与 えることが予想される。 また, 幼児の健康度や運 動能力と身体活動量の関連も多く報告されている (加賀谷ほか, 2003 ; Fisher et al., 2005 ; 清水ほか, 2006 ; 中野ほか, 2010)。これらのことから, 幼児 期における一定水準以上の身体活動の確保は重要 であるといえる。

国内外を問わず，子どもが健康であるためにど の程度の身体活動が必要かについては様々な研究 がなされており, Tudor-Locke et al. (2011)のレ ビューによると, 幼児における日常身体活動の目 標值として 1 日の総歩数は 10,000 歩〜 14,000 歩, 中強度以上の活動は 60 分〜 100 分とされてい る. しかし, 幼児を対象とした身体活動と様々な 健康指標との関連については, 大規模調査では質 問紙による検討が中心であり, 歩数や中・高強度 活動時間などの実測值による検討を行っている研 究はまだ少ないため, 科学的なエビデンスが求め られている。

WHO やアメリカ，イギリスなどの諸外国では 早くから幼児を含む子どもの身体活動ガイドライ ンが出されている（堀内ほか, 2008)。一方わが国 では, 日本体育協会（2010）から身体活動量の最 低基準として「中強度以上の活動を一日 60 分」と するガイドラインが，また文部科学省幼児期運動 指針策定委員会（2012）からは「幼児は様々な遊 びを中心に, 毎日, 合計 60 分以上, 楽しく身体を 動かすことが大切」とする幼児期運動指針が発表 されたばかりである。しかし, 文部科学省 (2011) の全国調査によると, 幼児の外遊びの時間は一日 60 分未満が 4 割を超えるという実態が報告され ており，身体活動を増やすための取り組みが必要 な状況であるといえる。これに伴い，保育現場で も身体活動の確保に努めているものの，幼览の身
体活動を数量的に評価することは保育者にとって 容易なことではなく，実際の保育につながる分か りやすい指標が求められている.

幼児の身体活動は保育施設による差が大きく， 園の環境や活動内容によって影響を受けることが 報告されている（Pate et al., 2004 ; Sugiyama et al., 2010)。また, 菊池ほか (2002) は, 保育者が意図 的に運動を取り入れると, 普段活発でない幼児ほ ど身体活動量の増加が期待できることから, 運動 量確保のためには保育者の働きかけや保育内容が 重要であると指摘している。このように保育者が 園でどのような活動を取り入れるかは幼児の身体 活動量の多寡に影響を及ぼすといえる.

ところで, 田中・田中 (2013), 石沢ほか (2011b), Chen et al. (2002) によると, 保育者が主観的に評 価した幼児の身体活動水準は，実際の活動水準と 一致し, 保育者から活発であると評価された幼児 は不活発であると評価された幼児よりも一日を通 した歩数や身体活動強度の実測值が高かったこと が報告されている。このことから，保育者の主観 的な評価は幼児の身体活動水準を把握する手段と して有効であると考えられる。

しかし, 両者の身体活動水準の差が保育中のど のような場面で現れるのかについての研究は少な く, 本田 (1999) が歩数に関しての検討を行って いるものの, 強度を含めた詳細な検討はなされて いない.

そこで, 本研究では, 保育者からの主観的な身 体活動水準の評価が異なる幼坚を対象に, 保育中 の活動場面による身体活動水準（強度と時間）を 比較し, 幼児の身体活動の確保につながる示唆を 得ることを目的とした。

\section{II 研究方法}

\section{1. 調査の概要}

東京都内の保育所に通う 4 歳児クラス・ 5 歳児 クラスの幼児 39 名を対象に, 活動量計を用いて 保育時間内の身体活動を測定し, クラスごとの平 均值を比較した。

また，保育者からの身体活動水準の評価が異な る幼児について, 保育中の活動場面による身体活 動水準を比較するために, 保育者に, 幼児の日常 
の身体活動水準を主観的に評価してもらった。 そ の上で，各クラスの子どもの中で「活発である」 「活発ではない」と判断された男女各 1 名（合計 8 名）を対象にビデオ撮影を行い, 活動量計による データとの照合を行った。

担任保育者の保育経験年数は 15 年以上で, 調 査対象園の属する区で行われている運動遊びプロ グラムの研修会等に参加しており, 子どもの活動 や運動遊びの大切さを理解していた。 また, 活動 量測定の経験もあり, 子どもたちの現状について の把握も十分にできていたと考えられる.

まず全体の傾向を把握するために, 保育所在園 中の歩数および中・高強度活動時間の比較を行っ た。次に観察および分析対象とする活動内容を身 体活動に影響を与えることが予想される自由遊び と一斉活動の運動遊び（各 30 分間）とし, 中・高 強度活動時間を指標として, 身体活動水準を比較 した。 また, 活動場所による違いも検討するため, 運動遊びは(1)公園, (2)園庭, (3)室内の 3 ケ所で実 施した。

なお, 本研究における一斉活動の運動遊びとは, 担任保育者によるクラス単位での遊び (鬼ごっこ や忍者ごっこ，ドッジボールなど）のことであり， 特定種目の技術向上を図る運動指導とは異なるも のである.

調査にあたっては，保護者に対して協力依頼お よび実施方法について資料を配布し，説明をした 上で書面による同意を得た。本研究は白梅学園大 学研究倫理委員会の承認を得て実施した。

\section{2. 身体活動}

1) 身体活動の測定

身体活動（歩数および中・高強度活動時間）は 3 軸加速度計つき活動量計（オムロン社製, Active style Pro HJA-350 IT）により測定した。活動 量計は，著者が作成した特製ベルトの収納ケース に入れ，そのベルトを対象児の腰部に装着し，保 育中の歩数および活動強度を記録した。また，測 定数值やボタンが見えることで, 幼児が数を意識 していつも以上に動いたり, 不要なボタン操作を したりしてしまう可能性があるため, 活動量計は ベルトに縫いこんで見えないようにした，活動量 計は, 保育時間内の活動状況を測定するために,
ほとんどの幼児が登園し終える9 時から, 順次降 園し始める 16 時までの間, 着替えや昼寝を除い て装着することとした。 また，保育者には活動量 計装着時の保育中の活動概要を記録してもらっ た。

記録したデー夕は専用ソフト OMRON BI-LINK 活動量 PRO を用いて処理し, 解析を行った。保 育時間内の測定は月曜から金曜までの平日 5 日間 行い, クラス全体の平均值の算出には欠席や遅刻, 早退などを除き 3 日以上のデータがある幼児を採 用した。

2 ）中・高強度活動の設定について

低年齢の子どもの身体活動の特徵は，遊びが中 心で, しかも短時間の間欠的な低・中・高強度の 様々な活動を含むことである（田中・田中, 2010）. そのため, 本研究では強度に着目し, 上下方向だ けでなく, 左右, 前後の水平方向も感知し, 歩行 以外の動きも捉えやすい 3 軸加速度計付き活動量 計を使用し, 10 秒ごとに活動強度を記録すること にした。

幼児の身体活動の強度について, 塩見ほか (2003) は中程度の運動強度は 3.5 METs〜6 METs としている。 また, 角南ほか (2004) の研 究では走行と歩行の閾值は 3.5 METs であったこ とが報告されており, 中強度の運動強度の METs 值については必ずしも一致していない，また，使 用する活動量計によって, 活動強度の算出式が異 なるため, 研究者間で中・高強度活動の定義が異 なることが指摘されている（田中・田中，2010）. 石沢ほか (2011a) の研究でも, 成人と同様に 3 軸 活動量計の 3 METs を中強度のカットオフポイン トとすると, 過大に評価される可能性が高いこと が指摘されている.

そこで筆者らは, 事前調査として, 幼児 $(2$ 歳〜 6 歳) 4 名を対象に日常生活や遊びに含まれる動 き（歩く，走る，跳ぶ，階段昇降，ボール投げな ど）の様子をビデオで撮影し，ビデオによる動き と活動量計による活動強度の測定值を照合した。 その結果, 今回使用する 3 軸活動量計 (オムロン 社製, Active style Pro HJA-350 IT）では, ゆっく り歩行は 2〜3 METs, 速歩は 4〜 5 METs, 走行は 6〜10 METs を示した.

この結果をもとに, 本研究では, 速歩程度とな 
る 4 METs を中強度のカットオフポイントとして 中・高強度の活動時間について比較を行うことと した。また，この活動量計では中・高強度活動時 間は水平方向の移動である「走・歩行」，と「走・ 歩行以外」の活動に分けての検出もできるため, それぞれの分析も行った。

表 1 保育所での活動概要

\begin{tabular}{|c|c|}
\hline 時刻 & 活動内容 \\
\hline $7: 00 \sim 9: 00$ & $\begin{array}{l}\text { 順次登園 } \\
\text { 自由遊び }\end{array}$ \\
\hline $9: 00 \sim 11: 30$ & $\begin{array}{c}\text { 自由遊び } \\
\text { または } \\
\text { 一斉活動 }\end{array}$ \\
\hline $11: 30 \sim 12: 30$ & 昼食 \\
\hline $13: 00 \sim 15: 00$ & お昼寝·着替え \\
\hline $15: 00 \sim 15: 30$ & おやつ \\
\hline $15: 30 \sim 16: 00$ & 自由遊び \\
\hline $16: 00 \sim 19: 00$ & $\begin{array}{l}\text { 自由遊び } \\
\text { 順次降園 }\end{array}$ \\
\hline
\end{tabular}

\section{3. 統計処理}

クラスごとの歩数と中・高強度活動時間の比較 では, SPSS Virsion21.0 for Windows を用いて性 別と年齢の 2 要因の分散分析を行い, 有意な交互 作用が認められた場合には単純主効果の検定を 行った。有意水準はいずれも5\%未満とした.

\section{III 結 果}

保育所での一日の活動概要を表 1 に示した. 昼食や昼寝, おやつの時間を除くと活動の中心は 9 時〜 11 時 30 分と 15 時 30 分〜 16 時の間であっ た。 また，対象者の年齢および身体特性は表 2 の 通りであった。

$4 \cdot 5$ 歳児クラス全体の 5 日間の平均歩数および 中・高強度活動時間を表 3 に示した（以後，4歳 児クラス男児を 4 歳男児のように表記).

2 要因の分散分析を行った結果, 歩数について は年齢および性別による主効果に有意な差が認め られ，女児より男児，4歳児より5 歳児の方が多 いことが分かった。

表 2 対象者の年齢および身体特性

\begin{tabular}{c|c|c|c|c|c}
\hline \multicolumn{2}{c|}{} & 人数 & 年齢 (歳) & 身長 $(\mathrm{cm})$ & 体重 $(\mathrm{kg})$ \\
\hline \multirow{2}{*}{ 男児 } & 4 歳児クラス & 10 & $4.8 \pm 0.2$ & $104.4 \pm 2.8$ & $16.4 \pm 1.8$ \\
\cline { 2 - 7 } & 5 歳児クラス & 10 & $5.7 \pm 0.3$ & $110.0 \pm 4.2$ & $18.4 \pm 1.7$ \\
\hline \multirow{2}{*}{ 女児 } & 4 歳児クラス & 10 & $4.8 \pm 0.3$ & $104.4 \pm 4.1$ & $15.9 \pm 1.3$ \\
\cline { 2 - 7 } & 5 歳児クラス & 9 & $5.7 \pm 0.3$ & $112.6 \pm 4.4$ & $18.7 \pm 1.5$ \\
\hline \multicolumn{4}{|c|}{ (平均值士標準偏差) }
\end{tabular}

表 34 . 5 歳児クラス全体の平均歩数および中・高強度活動時間

\begin{tabular}{|c|c|c|c|c|c|c|c|}
\hline & & \multirow{3}{*}{ 人数 } & \multirow{3}{*}{ 歩数（歩） } & \multicolumn{4}{|c|}{ 中・高強度活動時間（分） } \\
\hline & & & & \multirow{2}{*}{ 全体 } & \multicolumn{3}{|c|}{ 内訳 } \\
\hline & & & & & 走·歩行 & 走 · 歩行以外 & \\
\hline \multicolumn{2}{|c|}{ 全体 } & 39 & $4274 \pm 857$ & $42.3 \pm 11.2$ & $24.3 \pm 6.9$ & $18.0 \pm 6.0$ & \\
\hline \multirow{2}{*}{ 男児 } & 4 歳児クラス & 10 & $4632 \pm 741$ & $43.3 \pm 13.07$ & $26.7 \pm 7.3$ & $16.6 \pm 6.0$ & \\
\hline & 5 歳児クラス & 10 & $4702 \pm 703$ & $43.1 \pm 7.9$ & $26.6 \pm 5.2$ & $16.4 \pm 5.3$ & 7 \\
\hline \multirow{2}{*}{ 女児 } & 4 歳児クラス & 10 & $3427 \pm 647$ & $33.8 \pm 8.2$ & $18.4 \pm 5.5$ & $15.5 \pm 3.67$ & * \\
\hline & 5 歳児クラス & 9 & $4340 \pm 742$ & $49.6 \pm 10.6$ ]* & $25.6 \pm 6.4$ & $23.9 \pm 5.5^{*}$ & \\
\hline \multirow{2}{*}{ 主効果 } & \multirow{2}{*}{\multicolumn{2}{|c|}{$\begin{array}{l}\text { 年齢 } \\
\text { 性別 }\end{array}$}} & \multirow{2}{*}{$\begin{array}{r}4.690^{*} \\
11.899^{*}\end{array}$} & \multirow{2}{*}{$\begin{array}{l}5.755^{*} \\
0.213\end{array}$} & \multirow{2}{*}{$\begin{array}{l}3.316 \\
5.485^{*}\end{array}$} & \multirow{2}{*}{\multicolumn{2}{|c|}{$\begin{array}{l}6.255^{*} \\
3.564\end{array}$}} \\
\hline & & & & & & & \\
\hline 交互作用 & \multicolumn{2}{|l|}{ 年齢 $\times$ 性別 } & 3.449 & $6.074^{*}$ & 3.454 & \multicolumn{2}{|l|}{$6.740^{*}$} \\
\hline
\end{tabular}


表 4 観察対象者の年齢, 身体特性, 平均歩数および中・高強度活動時間

\begin{tabular}{|c|c|c|c|c|c|c|c|}
\hline \multirow{3}{*}{ 対象児 } & \multirow{3}{*}{ 年齢（歳） } & \multirow{3}{*}{ 身長（cm） } & \multirow{3}{*}{ 体重（kg） } & \multirow{3}{*}{ 歩数 (歩) } & \multicolumn{3}{|c|}{ 中·高強度活動時間（分） } \\
\hline & & & & & \multirow{2}{*}{ 全体 } & \multicolumn{2}{|c|}{ 内訳 } \\
\hline & & & & & & 走·歩行 & 走·歩行以外 \\
\hline 4 歳男（活発） & 5 歳 1 力月 & 107.8 & 18.0 & $5259 \pm 1710$ & $57.8 \pm 16.4$ & $36.2 \pm 15.8$ & $21.6 \pm 4.6$ \\
\hline 4 歳男 (不活発) & 5 歳 O 力月 & 103.7 & 14.7 & $4830 \pm 1570$ & $30.7 \pm 8.4$ & $20.9 \pm 6.7$ & $9.8 \pm 2.3$ \\
\hline 4 歳女（活発） & 4 歳 5 力月 & 98.0 & 14.2 & $3404 \pm 1492$ & $38.0 \pm 11.6$ & $19.6 \pm 10.8$ & $18.4 \pm 4.8$ \\
\hline 4 歳女（不活発） & 4 歳 6 力月 & 100.6 & 15.5 & $2435 \pm 1452$ & $23.6 \pm 11.7$ & $10.8 \pm 9.1$ & $12.8 \pm 4.9$ \\
\hline 5 歳男（活発） & 5 歳 11 力月 & 111.6 & 18.8 & $5660 \pm 2333$ & $62.5 \pm 19.3$ & $35.5 \pm 20.3$ & $27.0 \pm 4.9$ \\
\hline 5 歳男（不活発） & 5 歳 3 力月 & 107.0 & 16.8 & $4850 \pm 2119$ & $41.6 \pm 18.9$ & $31.9 \pm 19.9$ & $9.7 \pm 3.2$ \\
\hline 5 歳女（活発） & 6 歳 2 力月 & 119.0 & 20.0 & $4654 \pm 2023$ & $67.4 \pm 22.0$ & $32.8 \pm 19.6$ & $34.6 \pm 6.9$ \\
\hline 5 歳女（不活発） & 5 歳 5 力月 & 111.2 & 18.9 & $4163 \pm 2216$ & $47.3 \pm 18.5$ & $24.6 \pm 19.7$ & $22.6 \pm 6.3$ \\
\hline
\end{tabular}

表 5 自由遊びにおける中・高強度活動時間と主な活動内容

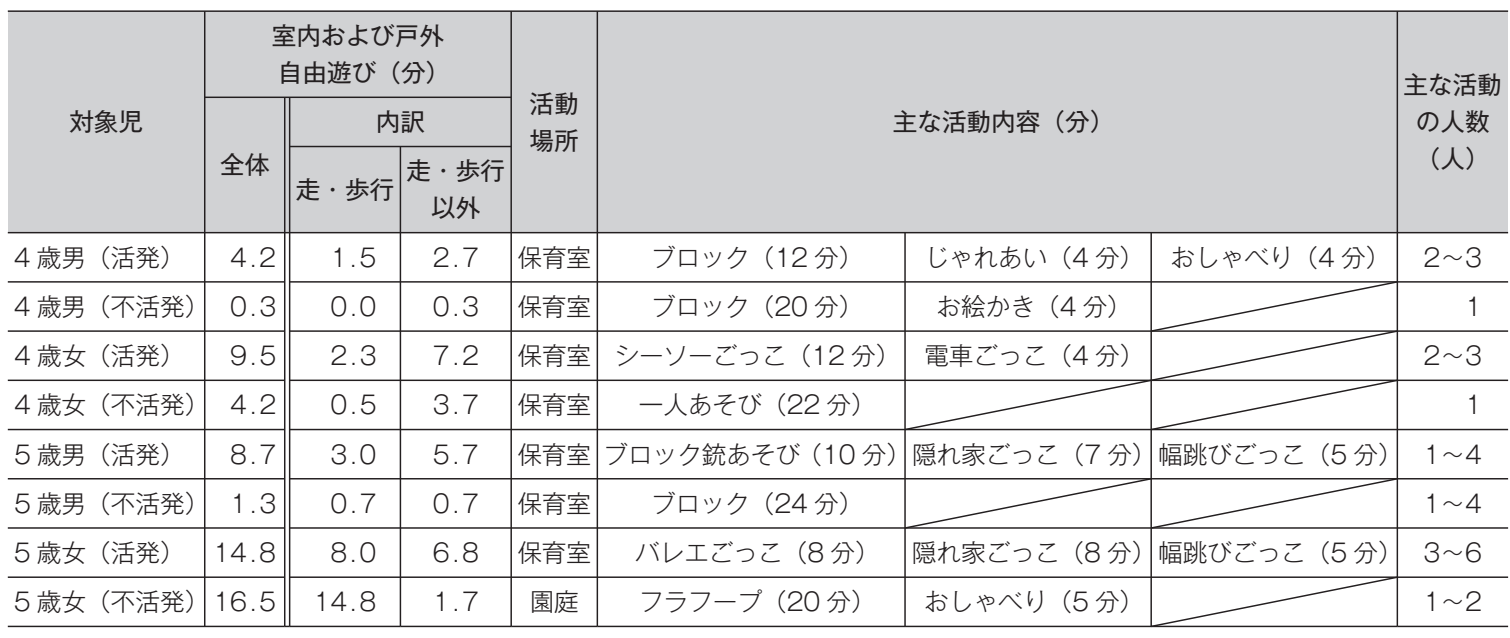

中・高強度活動時間においては有意な交互作用 が認められたため, 各要因で単純主効果の検定を 行ったところ，4歳児では男児の方が，女児では 5 歳児の方が有意に高い值であった.

同様に, 中・高強度活動時間の内訳をみると, 「走・歩行」では性別による主効果が有意であり， 男児のほうが高い值であった。また「走・歩行以 外」では, 有意な交互作用があり, 単純主効果の 検定の結果，5歳児では女児の方が，女児では 5 歳児の方が高いことが分かった.

活動ごとの観察対象となる幼児（8名）の年齢, 身体特性, 5 日間の歩数および中・高強度活動時 間の平均值を表 4 に示した，歩数および総中・高 強度活動時間の值は, いずれの性・年齢でも保育
者からの評価が活発な子ども（以後,「活発な子ど も」）よりも保育者からの評価が不活発な子ども (以後,「不活発な子ども」)の方が低い值を示した. 中・高強度活動時間の内訳をみると,「活発な子ど も」は「走・歩行」,「走・歩行以外」のいずれも 「不活発な子ども」より高い傾向がみられた。

自由遊びにおける中・高強度活動時間と主な活 動内容は表 5 のとおりである。観察対象日は晴 天であったが，ほとんどの子どもが保育室で活動 しており，全体的に活動量は少なめであった，活 発さによる中・高強度活動時間の比較では, 園庭 でフラフープをしていた 5 歳女児を除き,「不活 発な子ども」の值が低い傾向がみられた。 また, フラフープは主に腰部を動かす動きであるため 
表 6 一斉活動の運動遊びにおける中・高強度活動時間

\begin{tabular}{|c|c|c|c|c|c|c|c|c|c|c|c|c|}
\hline \multirow{3}{*}{ 対象児 } & \multicolumn{4}{|c|}{ 公園 運動遊び（分） } & \multicolumn{4}{|c|}{ 園庭 運動遊び（分） } & \multicolumn{4}{|c|}{ 室内 運動遊び（分） } \\
\hline & \multirow[b]{2}{*}{ 全体 } & \multicolumn{2}{|c|}{ 内訳 } & \multirow[b]{2}{*}{ 活動内容 } & \multirow[b]{2}{*}{ 全体 } & \multicolumn{2}{|c|}{ 内訳 } & \multirow[b]{2}{*}{ 活動内容 } & \multirow[b]{2}{*}{ 全体 } & \multicolumn{2}{|c|}{ 内訳 } & \multirow[b]{2}{*}{ 活動内容 } \\
\hline & & 走·歩行 & $\begin{array}{c}\text { 走. 歩行 } \\
\text { 以外 }\end{array}$ & & & 走·歩行 & $\begin{array}{c}\text { 走 · 歩行 } \\
\text { 以外 }\end{array}$ & & & 走·歩行 & $\begin{array}{c}\text { 走. 歩行 } \\
\text { 以外 }\end{array}$ & \\
\hline 4 歳男（活発） & 17.3 & 15.0 & 2.3 & \multirow{4}{*}{\begin{tabular}{|c} 
忍者ごつこ \\
水鬼
\end{tabular}} & 13.2 & 12.2 & 1.0 & \multirow{4}{*}{\begin{tabular}{|c|} 
ジグザグ \\
競争 \\
島鬼
\end{tabular}} & 14.7 & 9.8 & 4.8 & \multirow{4}{*}{$\begin{array}{c}\text { 忍者ごつこ } \\
\text { マット鬼 }\end{array}$} \\
\hline 4 歳男（不活発） & 10.8 & 10.5 & 0.3 & & 8.2 & 7.8 & 0.3 & & 7.5 & 5.7 & 1.8 & \\
\hline 4 歳女（活発） & 16.7 & 11.7 & 5.0 & & 12.5 & 11.0 & 1.5 & & 8.2 & 5.2 & 3.0 & \\
\hline 4 歳女（不活発） & 12.3 & 11.3 & 1.0 & & 10.0 & 8.5 & 1.5 & & 9.0 & 5.7 & 3.3 & \\
\hline 5 歳男（活発） & 20.2 & 19.8 & 0.3 & \multirow{4}{*}{$\begin{array}{c}\text { 水鬼 } \\
\text { トンネル鬼 }\end{array}$} & 19.0 & 18.5 & 0.5 & \multirow{4}{*}{$\begin{array}{l}\text { ドッジ } \\
\text { ボール }\end{array}$} & 14.7 & 2.2 & 12.5 & \multirow{4}{*}{ マット遊び } \\
\hline 5 歳男 (不活発) & 23.3 & 23.2 & 0.2 & & 20.2 & 20.0 & 0.2 & & 9.0 & 0.3 & 8.7 & \\
\hline 5 歳女（活発） & 21.0 & 19.7 & 1.3 & & 14.5 & 12.8 & 1.7 & & 13.2 & 1.0 & 12.2 & \\
\hline 5 歳女（不活発） & 18.0 & 17.2 & 0.8 & & 19.8 & 18.0 & 1.8 & & 8.5 & 0.7 & 7.8 & \\
\hline
\end{tabular}

か，活動量計ではほとんどが「走・歩行」に換算 されていた。

遊びの様子をみると,「活発な子ども」はほほ複 数で遊んで扔り，仲間と遊びを探したり，身体を 動かしたりしながら遊んでいる様子が多くみられ た。一方，「不活発な子ども」は一人で遊んだり， ブロックや揹絵描きなど，あまり動きを伴わない 遊びをしている傾向がみられた。

室内㧍よび園庭, 公園における一斉活動の運動 遊びでは，いずれも活発さによる中・高強度活動 時間の差が少なく, 保育者の評価が「不活発な子 ども」であっても, 高い身体活動水準を示した. 特に公園や園庭などの戸外の運動遊びでは活動水 準が高い傾向がみられた（表 6).

中・高強度活動時間の内訳をみると, 公園や園 庭での活動は鬼ごっこなど走り回る遊びが多かっ たため「走・歩行」がほとんどを占めたが，マッ 卜の上を転がったり, 忍者遊びでジャンプや這っ たりする動きが含まれていた室内遊びでは,「走・ 歩行以外」の割合が増えていた。

遊びの様子をみると,「活発な子ども」は遊びに 積極的に取り組んでいるだけでなく, 待ち時間に 走り回ったり，ルール確認や準備の間にもとび跳 ねたりするなど，遊び以外の場面でも自主的に体 を動かしていた，一方，「不活発な子ども」は，自 分から積極的には動き出さないが，遊びが始まる と一緒に走り回る様子がみられた。

事例として，4 歳女児の自由遊びと園庭での運 動遊びの活動強度のデー夕を挙げる（図 1)。自
由遊びをみると，「活発な女児」は $2 \sim 3$ 人の子ど もとかかわりながらシーソーごっこ(座って手を つないでのひっぱりっこ) や座って行う電車ごっ こを積極的に提案し，移動時にもスキップをする など自ら身体を動かして遊んでいた。

一方,「不活発な女児」は,一人で座って扔もちゃ で遊んだり，他の子どもの様子を見ていることが 中心で他児との会話も少なく, 中・高強度の值が みられたのは，遊びが見つからずにうろうろ歩き 回っている時と寝ころんでごろごろしている時で あった。

園庭での運動遊びでは, 忍者の修行として園庭 の遊具やコーンなどの障害を越えて走るジグザグ 競争とタイヤを使った島鬼を行った．ジグザグ競 争は全員が一列になって同時に走っていたため, 活発さに関わらず活動水準が高くなっていた。 そ の後，ジグザグコースでのリレーを行っており， 走る順番によって高い強度の出る夕イミングが異 なっていた，島鬼は全員がタイヤの周りを走り， 合図があると夕イヤの島に乗る遊びであった，集 合したり説明を聞いたりしている間の活動水準は 低いものの, 遊びの中では「不活発な子ども」で も中・高強度活動の頻度が高いことが分かった。

\section{IV 考察}

本研究では, 保育者からの主観的な身体活動水 準の評価が異なる幼児を対象に, 保育中の活動場 面による中・高強度活動時間を比較した．幼児期 

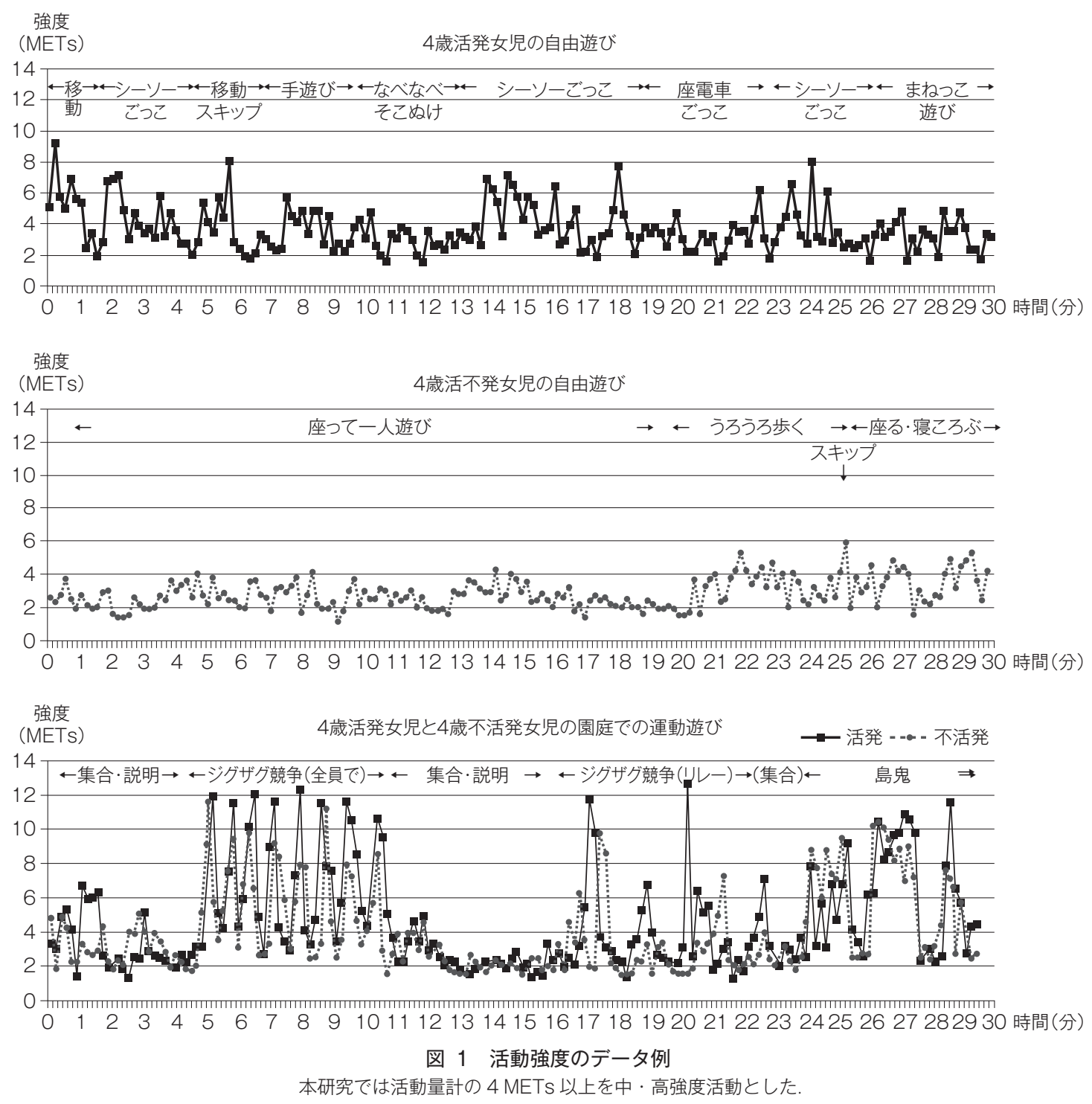

の身体活動の特徵に合わせ，短時間での様々な強 度の活動を捉えやすいように 3 軸加速度計付き活 動量計を使用し，ビデオ撮影により実際の活動内 容との照合をしたことに特徵がある。その結果, 自由遊びにおいては保育者の評価が「活発な子ど も」と「不活発な子ども」は活動内容の傾向が異 なり，中・高強度活動時間にも差がみられた。一 方, 一斉活動の運動遊びでは, 両者ともに中・高 強度活動時間の頻度が高く, 特に公園や園庭など 戸外での活動ではいずれの子どもも高い活動水準 を示すことが明らかになった。

\section{1. 保育時間内の歩数と中 ・高強度活動時間}

対象園の $4 \cdot 5$ 歳児クラス全体の平均歩数は $4274 \pm 857$ 歩, 中・高強度活動時間は $42.3 \pm 11.2$ 分であった．幼稚園または保育所在園時（9 時〜 14 時）の歩数および中・高強度活動（moderateto-vigorous physical activity）を調査した田中・田 中 (2009), 中野ほか (2010)の結果と比較すると, 本調査の対象児の歩数はやや少なめだが, 中・高 強度活動時間はおおよそ同等であったと考えられ る.

また, Brown et al. (2010), Sugiyama et al. (2010) は保育施設での在園時間の $80 \%$ ほどは座位の活 
動で, 中・高強度活動時間は 4〜 6\%しかなく, 幼 児の身体活動が少なかったことを報告している. 本研究では在園時間（7時間）の約 $10 \%$ が中・高 強度活動時間であり，保育時間内の中・高強度活 動が少ない点は同様の傾向を示した.

先行研究 (加賀谷ほか, 2003 ; 中野ほか, 2010) では, 男児より女児の平均歩数が少ないことが報 告されている. 本研究でも歩数および中・高強度 活動時間のうち「走・歩行」において, 同様の傾 向がみられたことから，全体的に男児の方が移動 を伴う動きが多いものと考えられる。しかし, 総 中・高強度活動時間および「走・歩行以外」の活 動では年齢や性別によって異なる傾向を示し, 特 に女児では 5 歳児の方が高い值となっていた。今 後は移動を伴わない動きにも着目してさらに検討 を進める必要があると考えられる。

観察対象者（8名）の個人デー夕を比較すると， 保育時間内の歩数および中・高強度活動時間の平 均值は，いずれの性・年齢でも保育者からの評価 が「活発な子ども」の方が高く，保育者の活発さ の評価と合致していた。 また，活発さによる歩数 の差は約 400〜1000 歩, 中・高強度活動時間の差 は約 15〜25 分となっており，「不活発な子ども」 の身体活動水準を高めることが課題であるといえ るだろう。特に不活発な 4 歳女児では他の子ども と比べてかなり低い活動水準を示した. Pate et al.（2004）による観察でも，3５歳の女児は男児 に比べて保育時間内の身体活動が明らかに少な かったことが報告されており，本研究の結果も合 わせると, 特に年齢の低い女児の身体活動を増や すための工夫が求められるであろう.

石沢ほか (2011b) は, 保育者の身体活動水準の 主観的評価は平均歩数よりも中・高強度活動時間 との関係が強いことを報告している. 本調査でも 活動水準の評価の違いによって, 中・高強度活時 間の差が大きかった：また，その内訳をみると， 「走・歩行」,「走・歩行以外」のいずれも「活発な 子ども」の方が高い值となっていたことから，「活 発な子ども」は遊びの中で走りまわっているだけ でなく, 跳躍, 回転など強度の高い様々な活動を 多く行っていることが明らかとなった。

\section{2. 自由遊びにおける活動水準に影響を与える 要因}

活発な幼児は自由遊び中の活動量が高いという 報告があるが (本田, 1999 ; 田中, 2009), 本研究 の結果はそれらを支持するものであった.

先行研究では複数で遊んでいる子どもは中・高 強度活動時間が長く (Nicaise et al., 2011), 運動能 力が高い（森ほか, 2004 ; 吉田ほか, 2004 ; 杉原 ほか，2010）ことが報告されている．本研究でも 自由遊びの際,「活発な子ども」はいずれも複数で 遊んでおり, 「不活発な子ども」のうち, 複数で遊 んでいる子どもは一人で遊んでいる子どもよりも 活動水準が高い傾向がみられたことから，複数で 遊ぶ機会を増やすと活動水準が高まる可能性があ ると考えられる。

また，鈴木（2006）や杉原ほか（2010）は子ど もの性格と身体活動や運動能力の関係について, 積極的, 社交的な子どもは活動量や運動能力が高 いことを報告している. 本研究でも「活発な子ど も」は積極的に他の子どもと関わり，身体を動か す遊びにも自主的に取り組んでいた。「活発な子 ども」は活動水準や運動能力が高まりやすく，ま すます自信を持って活動に取り組めるという相乗 効果につながる可能性が伺えた。

一方,「不活発な子ども」はブロックやお絵かき など一人で遊ぶ時間が長い傾向にあり, 仲間の誘 いがあれば一緒に活動するが, 自分から遊びを提 案することはほとんどなかった。 そのため, 運動 経験も不十分になる傾向にあり, 活動水準や運動 能力も低くなってしまう可能性があると考えられ る.このことから, 保育者は特に「不活発な子ど も」に対して，積極的に身体を動かしたくなるよ うな援助を心掛ける必要があるだろう。今回の観 察では，不活発な女览がフラフープを上手くでき たことを襄めてもらえたことをきっかけに，さら に意欲的に取り組む様子がみられた。このような 経験を繰り返していくことで自信がつき, 運動へ の意欲も高まるという一例であったと考えられ る.

\section{3. 一斉活動の運動遊びにおける活動水準の特 徵}

一斉活動の運動遊びでは，いずれも活発さによ 
る中・高強度活動時間の差が少なく, 保育者の評 価が「不活発な子ども」も「活発な子ども」と同 様に高い身体活動水準を示した。本田（1999）は 歩数において同様の結果を報告しているが, 本研 究では強度の面からみても活発さによる差がみら れず, 運動遊びの実施は「不活発な子ども」の身 体活動の確保に有効であることが示唆された．特 に公園や園庭などの戸外での活動水準は高い傾向 がみられたことから，戸外の運動遊びは幼児の身 体活動水準をより高める可能性があるといえるだ ろう.

小林ほか (1990), 岩田・春日（2010）によると, 鬼ごっこやドッジボールは活動量の多い遊びであ ることが確認されている. 今回の運動遊びで行わ れた鬼ごっこや忍者ごっこなども子どもたちが自 然に動き回れる要素が含まれており,「不活発な 子ども」も楽しんで取り組んでいる様子がみられ た。このような活動量が多く個人差の少ない遊び を一斉活動に取り入れることが，「不活発な子ど も」の身体活動を高めるのに有効であることが確 かめられた。

また, Sugiyama et al.（2010）は室内でも積極的 に運動遊びを行っている園の子どもたちは中・高 強度活動がより多く, 座位活動が少ないことを報 告している。本調査の結果では, 室内の運動遊び では, 戸外に比べると中・高強度活動のうち「走・ 歩行」の割合が低かった。 しかしその反面, 忍者 ごっこやマット遊びでジャンプしたり，転がった りする活動が含まれていたことから「走・歩行以 外」の割合が高く, 全体としてみると比較的高い 活動水準になっていた，幼児期は多様な動きを獲 得する時期であるため, 室内では這う, 転がるな ど様々な運動様式を取り入れる工夫をすること で, 活動量や強度だけでなく多様な動きの確保に も繋がる可能性があると考えられる。

\section{4. 本研究の限界と今後の課題}

活動量計の測定数值と映像を照合してみると, その場での運動であるフラフープはほとんどが 「走・歩行」として検出されていた. 幼児を対象と する場合は大人には見られない様々な動きをする 可能性があるため, 映像と活動強度のデー夕照合 が特に必要であると考えられる。
また, 今回は自由遊びの映像による分析は 1 回 ずつであったが, 自由遊びの内容は条件によって 異なる可能性があるため, 今後は複数回の継続的 な観察も必要であろう。

\section{$\mathrm{V}$ まとめ}

本研究では, 保育者の主観的な身体活動水準の 評価が異なる幼坚を対象に, 保育中の活動場面に よる身体活動水準（中・高強度活動時間）を比較 した。 その結果, 以下のことが明らかとなった。

1 ）保育者の評価が「活発な子ども」は「不活 発な子ども」よりも保育時間内の歩数および中 . 高強度活動時間の值が高く, 中・高強度活動時間 の内訳をみると, 「走・歩行」,「走・歩行以外」の いずれの活動においても出現頻度が高かった。

2 ）保育者の評価が「活発な子ども」と「不活 発な子ども」では, 自由遊びにおいて活動内容の 傾向が異なり, 中・高強度活動時間にも差がみら れるのに対して，一斉活動の運動遊びでは「不活 発な子ども」も「活発な子ども」と同程度の高い 活動水準がみられ，特に公園や園庭など戸外での 活動ではいずれの子どもも高い活動水準を示し た。

3 ）一斉活動の運動遊びの中・高強度活動時間 の内訳をみると，公園や園庭など戸外での活動で は「走・歩行」の割合がほとんどを占めていたが, 室内での運動遊びでは戸外よりも「走・歩行以外」 の割合が高まり，活動場所や内容によって違いが みられた。

これらのことから，保育者が戸外と室内におけ る活動や遊びの運動特性を理解し, 一斉活動での 運動遊びを適切に取り入れることにより，「不活 発な子ども」の身体活動水準を高める可能性が示 唆された。

\section{謝 辞}

本研究の調査にご協力いただいた保育所の園児お よび教職員の皆様に心より御礼申し上げます.

付 記

本研究は中野区幼児研究センターの調査研究の一 
環として行われた。平成 22 年度一 24 年度科学研究費 補助金 (基盤研究 (C) 課題番号 : 22610017 , 研究代表 者：松蒡洋子）の研究成果の一部である.

\section{文献}

Andersen, L. B., Harro, M., Sardinha, L. B., Froberg, K., Ekelund, U., Brage, S. and Andersen, S. A. (2006) Physical activity and clustered cardiovascular risk in children : a cross-sectional study (The European Youth Heart Study), Lancet, 368, 299-304

Brown, W. H., Pfeiffer, K. A., McIver, K. L., Dowda, M., Addy, C. L. and Pate, R. R. (2009) Social and environmental factors associated with preschoolers' nonsedentary physical activity, Child Dev, 80, $45-58$

Chen, X., Sekine, M., Hamanishi, S., Wang, H., Hayashikawa, Y., Yamagami, T. and Kagamimori, S. (2002) The validity of nursery teachers' report on the physical activity of young children, J Epidemiol, $12,367-374$

Fisher, A., Reilly, J. J., Kelly, L. A., Montgomery, C., Williamson, A., Paton, J. Y. and Grant, S. (2005) Fundamental movement skills and habitual physical activity in young children, Med Sci Sports Exerc, 37, 684-688

本田 㯖（1999）幼稚園・保育園における保育中の運 動量 : 園による差, カリキュラムによる差（効果 的な運動および体力向上に関する研究：主任研究 者: 村田光範), 厚生科学研究子ども家庭総合研 究事業平成 11 年度報告書, 234-235

堀内明子, 大場ゆかり，竹中晃二（2008）日本の子ど もに扔ける身体活動・運動の行動目標設定と効果 の検証一第 2 報一子どもを対象とした身体活動 ガイドライン：その国際的動向, 平成 19 年度日 本体育協会・スポーツ医・科学研究報告 II , 4-13

石沢順子, 佐々木玲子, 松峷洋子, 吉武 裕 (2011a) 保育園に通う幼児の日常身体活動量, 東京純心女 子大学紀要, 15, 21-28

石沢順子, 佐々木玲子, 吉武 裕 (2011b) 保護者およ び保育者からみた幼児の活発さと身体活動量の 関係, 体力科学, 60,714

岩田直人, 春日晃章（2010）子どもの活動量からみた 各種伝承遊びの特性, 岐阜大学教育学部研究報告 (自然科学)，34，123-127

加賀谷淳子, 清水靜代, 村岡慈歩, 岡田知雄, 西田ま すみ, 木村有里, 大森芙美子 (2003) 歩数からみ
た幼児の身体活動の実態 : 子どもの身体活動量目 標值設定にむけて，J Exerc Sci, 13, 1-8

菊池透, 山崎 恒, 亀田一博, 樋浦誠, 仁科正裕,

内山 聖 (2002) 保育所における保育士の働きか

けと運動量の関係, 小児保健研究, $61,470-474$

小林寛道, 脇田裕久, 八木規夫 (1990) 幼児の発達運

動学, ミネルヴァ書房, 193-210

文部科学省（2011）体力向上の基礎を培うための幼児

期における実践活動の在り方に関する調查研究

報告書, $153-156$

文部科学省幼児期運動指針策定委員会（2012）幼児期 運動指針ガイドブック：毎日楽しく体を動かすた めに

森 司朗, 杉原 隆, 吉田伊津美, 近藤充夫 (2004) 園環境が幼児の運動発達に与える影響, 体育の科 学, 54, 329-336

中野貴博，春日晃章，村瀬智彦（2010）生活習慣およ び体力との関係を考慮した幼児における適切な 身体活動量の検討, 発育発達研究, 46, 49-58

Nicaise, V., Kahan, D. and Sallis, J., f. (2011) Correlates of moderate-to-vigorous physical activity among preschoolers during unstructured outdoor periods, Prev Med, 53, 309-315

日本体育協会監修，竹中晃二編（2010）アクティブ • チャイルド $60 \mathrm{~min}$ : 子どもの身体活動ガイドラ イン, サンライフ企画, 18-28

Pate, R. R., Pfeiffer, K. A., Trost, S. G., Ziegler, P. and Dowda, M. (2004) Physical activity among children attending preschools, Pediatrics, 114, 12581263

Spalding, K. L., Arner, E., Westermark, P. O., Bernard, S., Buchholz, B. A., Bergmann, O., Blomqvist, L., Hoffstedt, J., Naslund, E., Britton, T., Concha, H., Hassen, M., Ryden, M., Frisen, J. and Arner, P. (2008) Dynamics of fat cell turnover in humans, Nature, 453, 783-787

清水靜代, 村岡慈歩, 西田ますみ, 大森芙美子, 鈴木 育夫, 岡田知雄, 佐々木玲子, 加賀谷淳子 (2006) 幼児における調整力の発達と身体活動量との関 係, 慶應義塾大学体育研究所紀要, 45, 1-6

塩見優子, 松井 健, 池本貞子 (2003) 幼児用 METS を指標とした観察法による身体活動量の評価, 平 成 14 年度日本体育協会スポーツ医・科学研究報 告 No. 1 身体活動・運動アドヒアランス強化に関 する心理・行動科学的研究第 2 報, 87-97

杉原 隆, 吉田伊津美, 森 司朗, 筒井清次郎, 鈴木 康弘, 中本浩揮, 近藤充夫 (2010) 幼児の運動能 
力と運動指導ならびに性格との関係, 体育の科 学, $60,341-347$

Sugiyama, T., Okely, A. D., Masters, J. M., and Moore, G.

T. (2010) Attributes of child care centers and outdoor play areas associated with preschoolers' physical activity and sedentary behavior, Environ Behav, 44, 334-349

角南良幸, 塩見優子, 沖嶋今日太, 西牟田守, 吉武 裕, 足立 稔 (2004) 幼児の日常生活身体活動量 についての研究（第 1 報）：加速度計による身体 活動量測定の妥当性, 体力科学, 53,844

鈴木裕子（2006）幼児の身体活動性を高める要因の検

討, 名古屋柳城短期大学紀要, 28, 125-135

田中千晶, 田中茂穂（2009）幼稚園および保育所に通

う日本人幼児における日常の身体活動量の比較,

体力科学, 58, 123-130

田中千晶, 田中茂穂（2010）子どもにおける身体活動
量の評価, 体育の科学, $60,389-395$

田中千晶, 田中茂穂（2013）幼児における身体活動の 客観的評価と主観的評価との関係, 発育発達研 究, 58, 18-24

田中沙織（2009）幼児の運動能力と身体活動における 関連について：5歳児の 1 日の生活からみた身体 活動量を中心として, 保育学研究, 47 (2), 8-16 Tudor-Locke, C., Craig, C. L., Beets, M. W., Belton, S., Cardon, G. M., Duncan, S., Hatano, Y., Lubans, D. R., Olds, T. S., Raustorp, A., Rowe, D. A., Spence, J. C., Tanaka, S. and Blair, S. N. (2011) How many steps/ Day are Enough? For children and Adolescents, Int J Behav Nutr Phys Act, 8, 80

吉田伊津美，杉原隆，森司朗，近藤充夫（2004）家庭 環境が幼児の運動能力発達に与える影響, 体育の 科学, 54, 243-249

(受付 : 2012 年 10 月 19 日, 受理 : 2013 年 10 月 29 日)

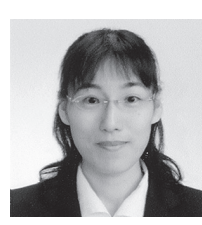

石沢 順子（いしざわ じゅんこ）

現職：相愛大学人間発達学部子ども発達 学科准教授

横浜国立大学大学院教育学研究科健康・スポーツ系教育専 攻修了, 修士 (教育学)。現在, 鹿屋体育大学大学院体育学 研究科博士後期課程在学中.

専門領域は発育発達, 野外教育. 現在は幼児の身体活動量 や運動能力を中心に研究を進めている.

保育者養成に携わるとともに, 東京都中野区幼児研究セン ター研究員として, 保育現場での運動遊びの調査や指導を 行っている. 平成 $24 \cdot 25$ 年度幼少年体育指導士認定講座 実技担当. 